\title{
Factors Limiting the Development of the Organic Food Sector-Perspective of Processors, Distributors, and Retailers
}

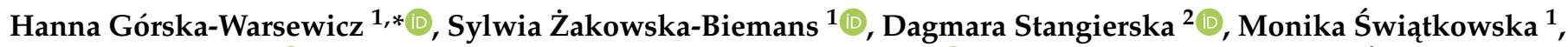 \\ Agnieszka Bobola $^{3}{ }^{\circledR}$, Julita Szlachciuk ${ }^{1}$, Maksymilian Czeczotko ${ }^{1}{ }^{(\mathbb{D}}$, Karol Krajewski ${ }^{4}$ and Ewa Świstak ${ }^{1}$ \\ 1 Department of Food Market and Consumer Research, Institute of Human Nutrition, \\ Warsaw University of Life Sciences, 02-787 Warsaw, Poland; \\ sylwia_zakowska_biemans@sggw.edu.pl (S.Ż.-B.); monika_swiatkowska@sggw.edu.pl (M.Ś.); \\ julita_szlachciuk@sggw.edu.pl (J.S.); maksymilian_czeczotko@sggw.edu.pl (M.C.); \\ ewa_swistak@sggw.edu.pl (E.Ś.) \\ 2 Department of Pomology and Horticulture Economics, Institute of Horticultural Sciences, \\ Warsaw University of Life Sciences, 02-787 Warsaw, Poland; dagmara_stangierska@sggw.edu.pl \\ 3 Department of Tourism, Social Communication and Counselling, Institute of Economics and Finance, \\ Warsaw University of Life Sciences, 02-787 Warsaw, Poland; agnieszka_bobola@sggw.edu.pl \\ 4 Institute of Technical Science, State Higher School of Eastern Europe in Przemyśl, 37-700 Przemyśl, Poland; \\ karol.krajewski@nikidw.edu.pl \\ * Correspondence: hanna_gorska_warsewicz@sggw.pl
}

Citation: Górska-Warsewicz, H.; Żakowska-Biemans, S.; Stangierska, D.; Świątkowska, M.; Bobola, A.; Szlachciuk, J.; Czeczotko, M.; Krajewski, K.; Świstak, E. Factors Limiting the Development of the Organic Food Sector-Perspective of Processors, Distributors, and Retailers. Agriculture 2021, 11, 882. https://doi.org/10.3390/agriculture 11090882

Academic Editor: Piotr Prus

Received: 10 August 2021

Accepted: 11 September 2021

Published: 15 September 2021

Publisher's Note: MDPI stays neutral with regard to jurisdictional claims in published maps and institutional affiliations.

Copyright: (c) 2021 by the authors. Licensee MDPI, Basel, Switzerland. This article is an open access article distributed under the terms and conditions of the Creative Commons Attribution (CC BY) license (https:/ / creativecommons.org/licenses/by/ $4.0 /)$.

\begin{abstract}
Our study aimed to explore the factors limiting the development of the organic food sector in Poland from the perspective of processing, distributing, and retailing companies. We used a qualitative approach with in-depth semi-structured interviews with the management board representatives of 17 large- and medium-sized enterprises and the owners of 10 small and medium companies. The potential limiting factors, including legal, economic, technological, and environmental factors, were identified by reviewing the corporate and market reports of processing and retailing companies operating in the Polish organic sector. We used a thematic analysis recommended in the literature to analyze qualitative data. The main factors indicated by the managers were the legal concerns, limitations resulting from a lack of constant supply of organic raw materials, and increased competition on domestic and international markets. In addition, business activities in the Polish organic sector were affected by the instability of the financial situation in terms of financial liquidity, adequate cost, capital structure, and credits. The results of the study may be of value for policymakers to ensure sustainable development of the organic food sector in Poland.
\end{abstract}

Keywords: limitation; organic food sector; legal limitations; economic limitations; technological limitations; environmental limitations

\section{Introduction}

Organic farming is considered a fast-growing agricultural sector in European Union (EU). In 2019, organic agricultural land, including in-conversion areas, in EU constituted 14.6 million hectares, and the total share of the organically managed area was estimated at $8.5 \%$ of the utilized agricultural area (UAA) [1]. Financial support through agri-environmental and rural development programs, which were developed based on the organic farming definition of Council Regulations (EC) 2092/91, has contributed to expanding the organically managed farms and areas under organic production in the EU countries [2]. Organic agriculture offers many advantages from a policy perspective and could be an important part of strategies that aim to improve the sustainability and equity of the food system as reflected in, e.g., The European Green Deal [3] and EU Farm to Fork (F2F) Strategy [4] as well as EU Biodiversity Strategy [5-8]. The main tenet of the Green Deal is the need to move to a more sustainable agricultural production system that minimizes the environmental footprint of agriculture, and organic farming is one of the 
key positive solutions to this problem [3,9-11]. The Biodiversity Strategy, which is part of this Plan, set itself the target of $25 \%$ of the agricultural land area for organic farming in the EU by 2030, compared to $8 \%$ currently allocated to organic farming in the EU and 3\% of organic agricultural land in Poland $[5,10,12,13]$. Many of the environmental concerns about conventional agriculture can already be alleviated by the current organic farming practices, which play an important role in mitigating greenhouse gas emissions [14].

Despite the existence of a common legal framework and support measures for the organic sector within EU Rural Development Programmes (RDP) [15], in some Member States, the share of the total organic area in the total UAA is well below the EU average. These Member States include Central and Eastern European countries such as Poland $(3.5 \%)$, Romania (2.9\%), and Bulgaria (2.3\%) [1]. The Polish organic farming sector experienced tremendous growth after the country's accession to the EU in 2004 when the subsidies for conversion and maintaining organic farming became available [16,17]. A similar phenomenon was observed in other new Member States during the post-accession period [18-21]. The number of organic farms in Poland grew rapidly until 2013, after which the trend reversed, and the organic farming area in the country decreased by $26.1 \%$ in the years 2015-2018 [21,22]. Policy support for organic farming in Poland was primarily focused on quantitative growth rather than on stimulating supply. As the payments were easily accessible and decoupled from production, subsidy-oriented farmers were encouraged to seek political rent. This resulted in the instability of a large group of farms who discontinued their organic farming activity [15].

Different types of factors influence the development of the organic sector, but the following groups are most frequently indicated as impeding the growth of organic farming: (1) management-related factors, (2) national policy on organic agriculture, (3) cultural barriers, and (4) market uncertainty [23]. This was also reflected in farmers' decisions to discontinue organic production due to economic reasons, concerns related to certification and production techniques, and macro-environmental issues [24,25]. Organic regulations are extremely complex and cover the entire food chain, including production, labelling, control, and import. The standards vary between regions; for instance, the EU standards differ slightly from the USA standards, while differences also exist within the EU because different national certification bodies follow different rules set by the EU [26]. Organic certification is conducted by an independent, impartial and competent certification body giving third-party assurance that all products traded as organic have been produced and processed according to the respective standards [27]. The credibility of the third-party certifier itself is backed up by accreditation, either provided by the private or by the public sector often with the consent of public authorities as in Poland, Spain, Malta, and Luxembourg [28,29]. Organic producers must comply with the legal requirements of organic production, fulfil administrative tasks, and undergo inspection to prove their conformity with organic regulations [28]. The organic control and certification system is not standardized across the EU, and different interpretations of specific requirements may exist [30]. Producers find it difficult to apply the rules concerning the labelling of organic products and meet the requirements set by certification bodies [30]. Another issue is the impact of general fiscal regulations on the financial performance of organic producers. Strategies designed for enhancing organic production should include tax reductions/exemptions for organic food producers [31]. To increase production efficiency and competitiveness, the taxation system should include significant measures and instruments for reducing the costs of organic production [32].

As in many other EU countries, the organic demand in Poland is growing faster than the organic area, thereby posing many challenges to producers and other actors of the organic supply chain [21]. Based on the analyses of the Polish organic sector, the barriers to the development of organic farming are classified into production-economic, market, and institutional-regulatory barriers [17]. Organic products, particularly organic packaged goods, are becoming more prevalent in Poland, including the mainstream channels such as discounters and hypermarkets, which was one of the key drivers of the growth value 
of $10 \%$ recorded in 2016 [33]. An obstacle that hinders the entry of organic products into mainstream retailers is farmers' reluctance to cooperate, as well as a lack of professional organizations dealing with organic logistics and sales, which reduces the potential for creating a common offer, especially in the case of small-sized organic farms having a significant share in the Polish organic sector [34-36]. A similar situation is observed in other countries struggling to develop their domestic organic markets [19]. Market barriers are strictly linked to production barriers because low yields and limited access to fertilizers and seeds are considered by farmers as primary obstacles that prevent them from converting to organic production, which is largely responsible for the low levels of supply [17]. On the other hand, despite the shortage in supply, many Polish organic farmers strive to sell their produce [37]. This can be attributed to the fact that organic farms are geographically dispersed, which results in high distribution costs [38].

Evidence also indicates an increased focus on organic products in retail sales, with private labels of foreign origin gaining share from the sales of branded organic products in Poland [34]. If the organic sector grows further and distribution costs are lowered, organic consumer prices could decrease considerably [6,39]. The development of the organic food market in the country is affected by high prices, followed by insufficient consumer awareness, low availability of organic products, short expiry dates and low visibility in shops [40]. Motivated by health and environmental concerns, Polish consumers increasingly search for organic products $[40,41]$, but they are not convinced to pay more for products obtained through organic production [42,43].

To make organic farming a viable option, improvements should be made in several areas. These include pursuing a clear organic sector strategy, supporting a shorter organic supply chain that provides environmental and social benefits, increasing the accuracy of data collection regarding organic markets, and improving statistical processes [44].

Several studies have attempted to explain the motivations of farmers to adopt organic agriculture, but research works focusing on other actors of food chain are too scarce to understand the factors that drive the development of organic farming and organic food markets in different regions $[23,25,26,35,45]$. To attract farmers to organic production and persuade them that it is an economically viable option, it is crucial to gain a thorough understanding of the numerous factors influencing the development of organic processing and sales. Another important issue is identifying which policy support is needed to sustainably develop the domestic organic food market.

Our aim was to explore the factors that limit the development of the organic food market from the perspective of processors, distributors, and retailers operating in the Polish organic sector based on a qualitative approach. Our study fills a research gap by including processor, distributor, and retailer perspectives. To date, research on the organic food sector has focused on farmers and the determinants of agricultural production. Our study addresses the subsequent stages of the organic food sector, i.e., processing, distribution, and retailing.

\section{Materials and Methods}

\subsection{Study Overview}

The study was performed based on a qualitative approach. In-depth interviews were conducted within the research project entitled "Marketing, promotion and market analysis of the organic production in Poland, including opportunities and barriers of development" (financed by the Ministry of Agriculture and Rural Development). The research was carried out in accordance with the ethical principles related to a company understood in accordance with article 551 of the Civil Code [46]. We used a qualitative approach with depth semistructured interviews. The qualitative approach, which refers to the meanings, concepts, definitions, characteristics, methods, descriptions, and perceptions of things [47]. The semi-structured interview is a qualitative data collection strategy in which the researcher asks informants a series of predetermined but open-ended questions [48]. It is used to gather focused, qualitative textual data. This method offers a balance between the flexibility 
of an open-ended interview and the focus of a structured. It ensures gathering data on the experiences of participants. Such information can help to develop the investigation process from general topics (domains) to more specific insights (factors and variables) [49,50]. A semi-structured interview combines predefined questions like those used in structured interviews with the open-ended exploration of an unstructured interview [51].

\subsection{Study Description}

A total of 27 processing, distributing, and trading companies were included in the study. In the first stage of the research, 17 in-depth interviews were conducted with experts (presidents, directors, purchasing managers, sale managers) of large processors, distributors, and retailers. In the second stage, 10 interviews were conducted mainly with the owners of small- and medium-sized companies, dealing with processing and distribution of organic foods or both organic and nonorganic foods. We chose to divide the companies into two groups as the project aimed to understand the opinions of market leaders as well as small- and medium-sized companies. In the first group, we selected the largest companies, which are the leaders in the production, processing, and retailing, including discount retailing of organic foods. We assumed being a leader in processing and trading of the organic food sector as a selection criterion, with the goal of covering as much as possible of the Polish organic food sector. We received responses from directors and managers representing 17 of the largest companies in the sector, which account for over $50 \%$ of the organic food market in Poland. Two companies did not want to be interviewed. The conversations that preceded the personal interview demanded our special attention. For the second group of companies, which included small- and medium-sized enterprises, arranging an interview date was much easier. The interviews were held at the companies' headquarters or business locations; in one case, a management representative visited our university for the interview.

The interview guide was prepared according to the recommendations in the literature that address the following steps: (1) an introduction to the purpose and topic of the interview, (2) a list of topics and questions to ask about each topic, (3) suggested probes and prompts, and (4) closing comments [51]. The questions in the interview guide are described to achieve the richest possible data [52].

Each interview was recorded and lasted between 120 and $150 \mathrm{~min}$. The results of the interviews were transcribed in a specially prepared matrix and subject to qualitative expert analysis. The matrix was designed in a way to facilitate the data analysis process. We used thematic analysis with verbatim transcriptions to capture every sentence the participant uttered and serve as an accurate record of the interview [53]. This research procedure is consistent with the accepted methodology of qualitative research in both data collection and analysis [50,53-56]. The data extracted from each interview was analyzed by two or three experts from our research team. After analysis at the individual level, the results and conclusions were discussed in joint workshops comprising eight experts.

\subsection{Participant Characteristics}

The characteristics of the 27 processing, distributing, and retailing companies included in the study is summarized in Table 1. The companies differed in terms of sales volume and number of employees. They provided organic or both organic and nonorganic products from various categories, including grain and cereal products, milk and dairy products, meat and meat products, and vegetables, fruits, and their products. The companies were coded from $\mathrm{C} 1$ to $\mathrm{C} 27$ to ensure their anonymity. 
Table 1. Description of companies that participated in the study.

\begin{tabular}{|c|c|c|c|c|}
\hline Company & Company Type ${ }^{1}$ & Product Type $^{2}$ & Product Group $^{3}$ & Company Size ${ }^{4}$ \\
\hline $\mathrm{C} 1$ & Processor/distributor & Organic & Mixed & Medium \\
\hline $\mathrm{C} 2$ & Processor & Mixed & $\begin{array}{l}\text { Meat and meat } \\
\text { products }\end{array}$ & Medium \\
\hline C3 & Processor/distributor & Mixed & Mixed & Large \\
\hline $\mathrm{C} 4$ & Processor & Mixed & $\begin{array}{l}\text { Milk and dairy } \\
\text { products }\end{array}$ & Medium \\
\hline C5 & Processor & Mixed & $\begin{array}{l}\text { Milk and dairy } \\
\text { products }\end{array}$ & Large \\
\hline C6 & Processor & Mixed & $\begin{array}{l}\text { Milk and dairy } \\
\text { products }\end{array}$ & Large \\
\hline $\mathrm{C} 7$ & Processor/distributor & Organic & Mixed & Medium \\
\hline $\mathrm{C} 8$ & Processor & Organic & $\begin{array}{l}\text { Vegetables, fruits, } \\
\text { and their } \\
\text { products }\end{array}$ & Small \\
\hline C9 & Processor/distributor & Organic & $\begin{array}{l}\text { Vegetables, fruits, } \\
\text { and their } \\
\text { products }\end{array}$ & Medium \\
\hline $\mathrm{C} 10$ & Processor/distributor & Organic & Oils & Medium \\
\hline C11 & Processor/distributor & Mixed & Mixed & Medium \\
\hline C12 & Processor & Organic & Mixed & Small \\
\hline $\mathrm{C} 13$ & Processor/distributor & Mixed & Mixed & Medium \\
\hline C14 & Processor/distributor & Organic & $\begin{array}{l}\text { Grain and cereal } \\
\text { products }\end{array}$ & Small \\
\hline C15 & Processor & Mixed & $\begin{array}{l}\text { Vegetables, fruits, } \\
\text { and their } \\
\text { products }\end{array}$ & Large \\
\hline $\mathrm{C} 16$ & Processor & Organic & Oils & Medium \\
\hline C17 & Retailer & Organic & Mixed & Medium \\
\hline $\mathrm{C} 18$ & Processor/distributor & Organic & $\begin{array}{l}\text { Vegetables, fruits, } \\
\text { and their } \\
\text { products }\end{array}$ & Medium \\
\hline C19 & Retailer & Mixed & Mixed & Large \\
\hline $\mathrm{C} 20$ & Retailer & Mixed & Mixed & Large \\
\hline $\mathrm{C} 21$ & Processor/distributor & Organic & Mixed & Large \\
\hline $\mathrm{C} 22$ & Retailer & Mixed & Mixed & Large \\
\hline $\mathrm{C} 23$ & Retailer & Mixed & Mixed & Large \\
\hline $\mathrm{C} 24$ & Retailer & Mixed & Mixed & Large \\
\hline $\mathrm{C} 25$ & Retailer & Mixed & Mixed & Large \\
\hline $\mathrm{C} 26$ & Processor/distributor & Organic & Mixed & Large \\
\hline $\mathrm{C} 27$ & Retailer & Mixed & Mixed & Large \\
\hline
\end{tabular}

${ }^{1}$ Type of company: production company (processor), distributor, retailer. ${ }^{2}$ Type of assortment: organic, mixed (organic and nonorganic). ${ }^{3}$ Type of products: dairy products; meat products; vegetables, fruits, and their products; mixed. ${ }^{4}$ Size of company: micro, small, medium, and large.

\subsection{Identification of Factors Decisive for Development of Organic Processing and Sales}

The limiting factors were identified by reviewing two types of reports. The first type analyzed were the reports of joint-stock companies listed on the Warsaw Stock Exchange. According to Polish law, these companies should publish a detailed financial report every year as well as so-called management reports on their activity. These reports contain operational and strategic information, including interpretation of financial results, customer and market analyses, and identification of risk and performance factors. We reviewed the reports of two of the largest companies in the context of risk factors and business drivers [31,57]. The second type of reports analyzed were annual reports of international retail chains listed on global stock exchanges [58-60]. These companies publish annual reports presenting comprehensive financial data and identifying various aspects of management, including risk factors, barriers to corporate growth, market growth prospects, and trends. We identified the activity-limiting factors in two stages. In the first stage, we 
extracted the limiting factors from the analyzed reports. In the second stage, we identified the recurring factors and prepared a list of 13 limiting factors. All the identified factors were discussed with the respondents during the in-depth interviews.

After the completion of interviews, we divided the limiting factors considering the specifics of the study (i.e., organic food sector) and the perspectives of processors, distributors, and retailers offering exclusively organic products or both organic and nonorganic products. Finally, there were four groups of limiting factors: legal, economic, technological, and environmental (including natural and social environment) (Table 2). The legal limitations included changes in legal regulations and different interpretations of legal regulations by the company and state authorities. The limitations related to the financial market situation (banking sector policy, interest rates, exchange rates), changes in exchange rates, and subjective assessment of the financial situation were grouped into a separate class-company financial status. All the identified factors were discussed with the respondents during interviews.

Table 2. Factors limiting the development of the organic food sector in Poland.

\begin{tabular}{cc}
\hline Groups of Factors & Limiting Factors \\
\hline Legal & Law changes and different legal interpretations \\
Fiscal state policy
\end{tabular}

\section{Results}

We presented the results in four sub-sections: 3.1-legal limitations, 3.2-economic limitations, 3.3-technological limitations, and 3.4-environmental limitations.

\subsection{Legal Limitations}

\subsubsection{Law Changes and Different Legal Interpretations}

The legal limitations for processors, distributors and traders were identified as: (1) complexity of organic and general food law, and (2) complexity of economic and business law.

In terms of organic activity, the law complexity referred to the issues of organic product certification and appropriate documentation. Documentation was mentioned as a concern for both farmers and processors; for farmers, it was about having and keeping proper documentation, while processors were additionally obliged to check the accuracy of the documentation kept by farmers.

"The farmer has to have documentation from the certification body, and we check that the farmer is doing all regularly." (C6)

The complexity of law concerning product and package labelling was also cited as a limiting factor, especially by processors.

"There are regulations regarding product labelling. Every word used on the label must comply with the law. All information on the packaging is carefully checked." (C5) 
Regarding economic and business law, the processing, distributing, and trading companies mentioned frequent changes in legal regulations as a factor limiting their business activities.

“( ... ) too frequent changes in regulations (... ) legal regulations intricate, incomprehensible." (C14)

Excessive regulation was also identified as a limiting factor, which highlights the existence of a bureaucratic system. This adds to the complexity of operating a business in the organic food sector in Poland when compared to other countries such as Germany.

"Bureaucracy." (C14)

"Legal barriers—too much difficulty in comparison with, e.g., Germany."

Another issue emphasized in the interviews was the discrepancies in the interpretation of the current legislation between the companies and the state administration. Managers pointed to various interpretations of business and administrative law regulations.

"We met with such a problem, which indicates a different interpretation of the legal regulations." (C6)

\subsubsection{Fiscal State Policy}

Fiscal policy refers to the use of fiscal instruments, such as taxes, the public deficit, and the public debt that affect the government budget. The instruments influencing the development of the organic food sector include taxes, fees, duties, and subsidies, which are of more significance for large- and medium-sized processing companies.

During the discussion of fiscal policy, the processing and trading companies indicated value-added tax (VAT), corporate income tax and social charges as limitations. They cited ambiguities in the current legislation as a source of discrepancies in the interpretation of tax regulations between tax authorities and enterprises. At the same time, they mentioned that additional tax liabilities resulting from an audit are subject to payment with accrued interest and thus increase the so-called tax risk.

"Too-high VAT rates." (C2)

Different VAT interpretations were found to be a separate limiting factor. In the case of Poland, this factor is related to different VAT rates. Respondents noted that general guidelines are available as to which products should be taxed at the standard rate (i.e., 23\%) and which at a reduced rate (e.g., $8 \%$ ). Applying a reduced rate to a product can pose some risk whether the decision is appropriate. This ambiguity of VAT rates is considered a limiting factor.

"Interpretation of VAT regulations is difficult." (C3)

"The tax settlement system is a barrier-for invoices VAT is supposed to go to another account and the rest to another, then everything will get complicated. Interpretation of VAT regulations is difficult." (C3)

\subsection{Economic Limitations}

\subsubsection{Increasing Competition in the Retail Market}

Increasing competition in the organic market can be linked to growing demand due to changes in consumer lifestyles and preferences and increasing health awareness. It may also result from the emergence of large companies in the market, which is related to the observed tendency for companies with well-recognized brands in nonorganic categories to begin organic food production.

"The problem is the price, the popularity of the brand (harder to break through), and the potential of the product. It is more and more difficult to break through because the brand is very important for consumers. The problem for suppliers is to maintain the "constant" quality of the product." (C20) 
An additional threat to existing retailers in the organic food sector is that specialist stores order products directly from processors. The respondents also stated the possibility of further assortment expansion by large retail chains as well as an increase in consumer interest in direct sales. On the one hand, these phenomena pose a threat to existing market participants, while on the other, they play an important role in the development of the organic food market and increasing its competitiveness.

"The biggest threat is the bazaars and so-called "food from a farmer". They should take care of it." (C5)

Increased competition for organic foods in the retail market may also decrease demand due to changes in consumers' lifestyles and competition from other products having similar attributes like local food. Another issue is that small companies have limited knowledge of product development and commercialization. They launch products without conducting market research, and as a result, their products do not meet consumers' expectations.

"Small processors should take care of product quality and standardization; farmers need to be more productive; in Poland the segment preparing the product for further sale is underdeveloped; processors create the product without market research." (C21)

Furthermore, the expansion of discount stores that offer organic products with private labels and at lower prices increases competition in the retail market. However, the strategy of these stores also improves the availability of organic foods.

\subsubsection{Seasonality of Supply and Demand}

The organic food sector is influenced by the seasonality of demand and supply, which determines the fluctuations in sales revenue. The representatives of some processing and distributing companies had an opinion that sales (in terms of volume) and revenues are the highest during winter and spring with an increase in the pre-holiday period, whereas the lowest sales are recorded during the holiday season. The amplitude of organic sales revenue fluctuations by some trading and manufacturing companies varies from 15-20\% above the average monthly sales revenue before Christmas and Easter to $15-20 \%$ below the monthly average during the holiday months.

"Periods of highest sales in March-June and October-November, a decrease in sales occurs in the holiday months (July-August) and December and January." (C14)

The seasonality of supply in organic production also forces organic companies to search for products from other countries and cope with fluctuating exchange rates and thus increased costs.

"The greatest enemy of organic is the seasonality of production. On organic farms, seasonality is much more noticeable because production is based on grasslands. In summer, cows produce much more milk than in winter; the differences are even double when looking at monthly deliveries." (C4)

"In case of raw material purchase, the seasonality of production is important." (C6)

According to the respondent, sale seasonality can be protected by activities that increase the range of organic products available throughout the year.

"The reason of cost increase is the purchase of raw material. (... ) we have additional storage costs (... ) We have the highest income in the last quarter. " (C26)

\subsubsection{Growing Competition on the Raw Material Market}

Increased demand for organic food leads to a higher demand for raw materials, resulting in more competition in the raw material market. This can be related not only to an increase in the number of companies looking for organic raw materials for food production but also to several external conditions. To deal with the growing competition, processors should develop different models of cooperation within the supply chain. They must focus on activities associated with the maintenance of existing suppliers while also attracting 
new ones, as well as introducing relationship management principles based on trust and value to ensure long-term cooperation. Moreover, the companies should make efforts to establish partnerships with importers.

"Contracting (... ), if some products are missing, we buy semi-finished products; we could sell a lot more, we need farmers delivering organic products."

"The quantity of raw material is insufficient, which is due to high (too strict) requirements for raw material."

One of the main obstacles to the development of partnership within the supply chain is the low number of organic producers' organizations. Organic farms are geographically dispersed, and farmers are reluctant to cooperate. This results in low production volume in each farm, which in turn leads to increased logistic costs.

"Poorly organized farmers, farmers unable to work together." (C1)

"The availability of raw material, in the beginning, was a nightmare. Today it is much easier to produce organic food; the availability has improved. There is a problem with farmers, most often, they don't have the right amount. (... ) We already have a base of suppliers, especially in the case of vegetables $3-4$ constant sources." (C3)

"We try to meet the demand, but it is usually greater than the amount of raw material." (C6)

\subsubsection{Dependence on Global Prices}

Due to limited access to raw materials and organic products of native origin, organic processors and retailers of Poland are highly dependent on other countries for sourcing products. This is particularly important in the case of companies procuring raw materials and/or selling their products in foreign markets. There is huge competition for raw materials and products from countries such as China, Chile, Spain, Lithuania, and Turkey. The purchase and sale prices of raw materials and products in foreign markets vary depending on the prices in those markets and changes in exchange rates.

"The price blocks the purchase of raw material from abroad. The same is true for feed

(... ). The feed is own for agricultural purposes; the rest is bought." (C2)

"Raw material from the west- price three times higher. We do not consider that there is no raw material, we do not even raise the price, but sometimes we buy raw material 2-3 times more expensive, just to have it." (C3)

Large retail companies cope with these challenges by adopting two options. The first option is a centralized supply under the supervision of the head office, and local supply to individual stores from local organic farmers. These solutions allow, on the one hand, to ensure continuity of supply and, on the other, to source products from local farmers. The second option is especially advantageous as it draws consumers' attention to the products of local origin and creates a positive image of the chain as an environmentally and socially responsible enterprise.

"There is no point in importing fruit from abroad, just a supplement is enough. We import red grape, pomegranate and cranberry juices; they are part of a healthy lifestyle." (C1)

\subsubsection{Macroeconomic Situation}

The macroeconomic situation is a factor that determines the gross domestic product, purchasing power, unemployment level, and economic growth rate. A slowdown in economic growth, increasing inflation and unemployment can all negatively affect the organic food market.

Demand for organic products is related to consumer expenditure, which in turn is influenced by the economic situation of households. The managers who were interviewed in the study were very much aware that deterioration of the macroeconomic situation may lead to a decrease in the demand for organic foods. At the same time, the consumer may begin to choose products of lower quality with "green labels". In addition, there may 
be changes in the purchasing behavior of potential consumers who only prefer buying organic products.

Financial market conditions are related to banking sector policies and interest rates. Liquidity is affected by interest rates on working capital and investment loans, while the level of liabilities determines the amount of debt owed by the company.

\subsubsection{Financial Limitations}

According to processors, distributors, and retailers, financial barriers refer to changes in the exchange rate, loss of liquidity, insolvency of cooperating companies, and increase in production costs.

Companies that purchase raw materials from foreign suppliers and importers must be aware of exchange rate fluctuations. Furthermore, companies that rent commercial space under lease agreements with rates set in euros face greater currency risk.

Fluctuations in the zloty to euro and dollar exchange rates as well as euro to dollar exchange rate have an impact on financial results as they influence the cost level. Changes in purchase and selling prices, on the other hand, make it difficult to manage margins and predict financial results. Unfavorable exchange rate fluctuations increase the cost of business and, consequently, reduce profits or exacerbate losses. This can be possibly overcome by raising prices, which may reduce demand.

Foreign exchange risk management is uncommon in companies in the organic food sector. Some stages of this process are identifying currency risk and determining currency position. The remaining steps, which include forecasting future exchange rates (or monitoring available forecasts), measuring the level of foreign exchange risk, and developing or selecting a strategy to hedge this risk, are only applicable to large retailers. During the interview, the managers of the organic food sector, stated their desire for euro settlements.

"We would like euro in Poland." (C19)

One of the main threats that affect the operation of producing or trading companies in the organic food sector is the loss of liquidity. Short-term liquidity problems result in reduced flexibility and modernization plans, a greater focus on day-to-day cash management, and restructuring efforts. Risk management involves cash and cash flow management, including forecasting. Additionally, while determining fixed asset investments, the levels of working capital and financial debt are monitored.

"You have to have extra cash reserves for possible slippage." (C14)

"We have a reserve. If we did not have our resource fund, it would be difficult; after all, we must put goods in warehouses, put goods in stores." (C4)

"We used to get credit before, so it gives us additional liquidity." (C1)

To preserve financial liquidity in organic food companies, it is essential to consider the insolvency of cooperators and the existence of overdue receivables. This includes the late payment of trade receivables and cash flow disruptions.

"We give payment terms of 21 days and want money for 21-28 days. However, suppliers are paid within 7 days after the month of delivery, and they have never been late. Large suppliers are paid after half a month." (C4)

"Payment to suppliers-within 14 days, for payment from customers wait approx. 40 days and they still have to remind each other." (C14)

"There are delays in payments sometimes affecting financial liquidity." (C15) 
The risk of cost growth refers to the costs of basic operations. For processing companies in the organic food sector, the costs include salaries and employee benefits and those related to materials and energy consumption and purchase of third-party services. The managers pointed to the following factors as contributing to the increase in costs:

- $\quad$ a significant increase in employee salaries and total labor costs,

- $\quad$ higher prices of organic raw materials and commercial goods, including those purchased from foreign partners due to unfavorable exchange rate fluctuations,

- increased EUR-denominated rents for sales and office space as well as for renovated locations,

- domestic transportation costs (in the case of small processors),

- higher international transportation costs,

- $\quad$ an increase in the cost of external services, and

- $\quad$ an increase in the cost of goods losses due to a variety of factors, including those related to changing the assortment toward a greater share of fresh products, which naturally contributes to an increase in warehouse losses (e.g., expired, spoiled goods).

For companies conducting commercial activity in leased premises, the risk related to lease contracts gains additional significance. On the one hand, long-term lease agreements such as 5 or 10 years, affect the stability of operations of retail outlets. On the other hand, the unfeasibility of early termination in the event of a decrease in profitability raises costs and precludes flexible management. Thus, the terms and conditions of lease agreements are an important element, but the freedom of business activity allows the interested parties to decide on them. A solution to overcome reduced profitability would be to reassign the premises to another type of business. However, this is complicated by the lack of possibility to extend the lease agreement, due to the costs of relocation of the place of business and adaptation of new premises to the needs of the given units. This kind of limitation applies to any commercial and service activity carried out in multiple locations in leased premises. Such a model of conducting business activity is widely popular due to the high costs of securing premises for ownership.

Among other operating costs, the costs of closing unprofitable retail outlets and creating provisions for this process were pointed out by retailers. The financial costs cited by them included foreign exchange differences, interest on credit, loans, and leases. In addition, they indicated the costs of issuing and maintaining bank guarantees to shopping centers as guarantees of rent payment.

Apart from the costs associated with day-to-day operations, costs resulting from new product launches were reported.

"Raw material a lot and getting more; energy; employees 20-30 people. Modernization and one shift; we don't work on Sundays and holidays, permanent employees, operating costs are increasing." (C1)

"Biggest costs-transport (small batches), diesel prices."

"Highest costs of employees (higher minimum wage, increase in employee costs, social security)." (C3)

"60-65\% as we have the cost analysis is, however, the raw material, then their wages $20 \%$, or their energy 10\%, or their fuel." (C4)

"The highest is raw material cost." (C5)

"The most important are costs of raw material and transport." (C6)

"Yes, we are seeing an increase in costs. Logistics affects the cost increase the most." (C19)

The assessment of financial status also includes a debt analysis that considers the current level of debt and the ability to cover it. The companies in the organic food sector can be affected by the following limitations: imbalance between long- and short-term debt, interest coverage, and excessive total debt. 
In this context, the limitations associated with the business activity of companies and the stability of the cash flows achieved should also be mentioned. Those companies that have relatively low risk and stable cash flows can make greater use of the external capital.

"Credit's too expensive, especially compared to other countries." (C15)

\subsection{Technological Limitations}

\subsubsection{Problems with Maintaining a Stable Raw Material Base}

This factor should be considered in two aspects for the organic food sector. On the one hand, working with many farmers necessitates the development of an appropriate model. Farmers are given sales, technical support, and training. This develops trust, which is a positive element of supplier relationship management. A close cooperation is also an incentive for other farmers who have the desire to convert to organic production, which explains why medium and large processing companies consider this factor highly important.

"The relationship with farmers is important and close. We know them, we sign contracts, we visit them before the season and during the season. The contracts are renewable every year. The farmer gets a certificate not only for the product but also for the quantity. (... ) It is worth introducing professional customer service standards, but we cannot forget about the human factor. Trust and closeness of these relations are the most important aspects; sale is by the way." (C26)

Openness to introduce new crops that can increase the profitability of organic farming is the first aspect. As the length of the cooperation grows, so does the trust in the relationship with farmers. This allows reacting quickly in situations that may have a negative impact on yields. Farmers trying to sell organic products at more attractive prices due to faster payment terms are at risk of losing some of their suppliers. This could happen if there is an increase in demand for organic foods.

The second aspect refers to the dependence on key suppliers. Companies that have one or more key suppliers for one or some of the raw materials or products may be at risk of withholding supplies. In the case of manufacturing companies and specialist stores, such a situation could lead to a temporary lack of supply of certain products and a temporary reduction in sales revenue.

"We pay attention to continuity and flexibility of supply. Generally, there is continuity, but sometimes there are products unavailable due to lack of raw material. We have several suppliers (one supplier does not necessarily have a comprehensive range). Mainly Polish suppliers". (C19)

This limitation is overcome by applying a supply diversification strategy, which allows covering the supply shortages caused by the withdrawal of one supplier by competing suppliers. Another option is to search for suppliers in other countries due to the breadth of product offerings, which can result in greater security of supply in the event of a possible supply deficit from one of the existing suppliers.

"If we are interested in a product, we will import from the furthest places. What is important is the attractiveness of the product and the reliability of suppliers, timeliness, comprehensiveness of supply. A big problem is incompleteness of deliveries (... ). Generally, cooperation with suppliers is good, rotation is very low, new suppliers come and old suppliers do not leave. (...) We negotiate with large and small producers." (C23)

\subsubsection{Logistic and Production-Storage Problems}

Crop seasonality determines the occurrence of surplus raw materials at specific times. At the same time, increasing demand for organic foods and sales can generate logistical and production-storage problems. Processing enterprises employ different strategies to offset this issue, which include the development of a distribution and logistics management system, as well as centralization of storage activities and enhancement of the production 
management system. Another aspect to be considered is the order volume resulting from transportation costs.

"The reason for the cost increase is the purchase of raw material. ( . . ) we have additional storage costs (...) We do not have our cold storage facilities, but this is not a targeted strategy." (C26)

"Problem-if you want to order a little because the minimum quantity is a pallet." (C3)

\subsubsection{Insufficient Number of Interventions for Plant Protection Products}

Reduced yields caused by the lack of use of plant protection products are another limitation in organic farming. This may be related to the occurrence of diseases and the presence of pests affecting the raw materials. This limitation can be alleviated by crop monitoring aimed at estimating yields and threats posed by diseases and pests. The respondents representing processing companies mentioned that they provide training on crop technology, mainly fruits and vegetables, as part of their supplier relationship management.

\subsection{Environmental Limitations}

The environmental limitations cover factors that are beyond one's control, such as weather conditions and sociocultural environment, which includes consumer trends and behaviors.

\subsubsection{The Negative Impact of Weather on Yields}

Organic farming is characterized by a high risk of weather changes and their impact on yields. Farmers are directly affected by losses resulting from reduced supplies to processors and distributors. Organic production of fruits and vegetables is highly prone to adverse weather changes. May frosts, which cause flowers to freeze, and droughts or heavy rainfall during the growing season can cause the highest losses for this group of organic foods.

"One lady made beets, very good, but 1.5-2 tons and the need were about 20 tons. This year she gave $500 \mathrm{~kg}$ because there was a crop failure." (C3)

Traders, as well as medium and large processing companies, perceived the impact of weather as important. This can be explained by the potential issues in delivering the required volume of supply and the need to make up the shortfall with raw materials and imported products. The negative effects of weather are offset by adopting a strategy of replenishing supplies in the domestic market and then looking for supply opportunities from foreign countries. This is facilitated by the diversification of suppliers, which reduces the dependence on one or several suppliers.

\subsubsection{Slow Changes in Consumer Preferences}

The managers of processing, distributing, and retailing companies emphasized that they notice a change in the lifestyle of consumers, with a greater focus on natural and organic products. Due to growing awareness of nutrition, consumers prefer purchasing fresh and healthy products. This trend is observed for organic products from different product categories. The motivation for buying organic foods also varies among consumers. Some consumers choose organic products as they are concerned about the health implications of a disease, such as cancer, while some have the desire to maintain good health in the future. Another group of consumers purchasing organic foods are young, conscious consumers, for whom the motive of choice is the health-promoting value and organic production.

"The main reason for buying eco food: health-promoting value. If someone cares about health, they buy unprocessed products, and they must be organic, because it has an added value right away. Poles choose eco, organic products are imported from abroad. Organic and bio were associated better at the beginning, as something Western (especially organic)." (C3) 
"Consumers are young people who care about their health and family. They know what the different symbols mean, although people confuse GMO-free products with organic products." (C6)

"There are three main groups of organic food consumers: (1) mothers of young children, (2) sick people requiring a healthy diet, (3) retirees." (C14)

\section{Discussion}

Our study analyzed the factors that limit the activities and development of the organic food sector in Poland with the aim of filling the gap in the existing literature on factors influencing the organic sector development from the perspective of processors, distributors, and retailers. Some studies have analyzed the limitations in the organic industry, but a large part of their findings was related to organic farming. Unfortunately, very few studies have focused on downstream links in the organic food distribution chain. In the following sections, we presented the discussion of results in the same order as the description of results.

\subsection{Legal Limitations}

Our research indicated that factors perceived as limiting the development of production and sales of organic foods in Poland are law changes and different interpretations of legal regulations by institutions that are responsible for supervising and controlling the organic farming and food sector. The managers from processing, distributing, and retailing companies indicated that they had noticed differences in the interpretations of legal regulations and frequent changes in tax law, labor law, social insurance law, or business condition regulations. Other studies have also emphasized the influence of political and legal factors, such as an underdeveloped institutional environment and lack of adequate financial support in the development and functioning of the organic food market [61]. A study conducted in Norway [62] revealed that economic and regulatory issues were mainly responsible for the abandonment of organic practices by farmers. The results of a study carried out among wine producers in Germany [63] are consistent with the responses of our interviews and confirmed that restrictive legislation and inconsistent or changing regulations regarding organic certification and control systems, including paperwork, inspections, and lack of trust in institutions, are barriers to the development of the organic market. A study from Denmark indicated that although farmers are aware of agrotechnology-based farm management, they have difficulty in applying the recommendations for organic production [64]. From a legal perspective, organic and regional foods are treated quite differently in the EU [65]. Complex legal regulations, contradictory interpretations, lack of sufficient institutional support, and high levels of uncertainty have been identified as important limitations to the development of the organic market [36,65-67]. In addition, a study has described the legal limitations related to the export of organic products [68]. The fear of losing independence when converting to organic farming, as well as the fear of being constrained by a wide range of complex rules and regulations, is also perceived as a significant issue [69].

Our study showed that regulations regarding product and packaging labeling have also been interpreted differently by organizations. Furthermore, interpretive differences in documentation and certification of processing and packaging were highlighted by respondents. A document prepared by the European Commission Directorate-General for Agriculture and Rural Development [70] based on frequently asked questions regarding organic regulations also confirms ambiguity in formal aspects. The questions were related to the organic labelling of products containing, among others, spirulina, oils, mushrooms, wild fish, and animal meat. Political and legal issues in the context of organic certification have been widely discussed in other studies [71,72]. The burden of maintaining certification documentation required to operate an organic farm is a major reason for both not starting and abandoning this activity [73], and has been identified as a "hassle factor" in organic food production [74]. Policy support provided for farming focuses mainly on 
productivity and undervalues sustainable farming practices [75]. Such regulatory limitations hinder the conversion of conventional farms and food processing companies into organic systems [76,77].

\subsection{Economic Limitations}

Our study indicated that increasing competition in the organic food market was perceived as an important limitation by retailing and processing companies. This is in line with the results of other studies $[65,78]$. Competition between processors who offer products at lower prices prevents the development of the organic food market, especially in terms of increasing the affordability of organic products for consumers [79]. Another problem is the competition of organic products with others, such as conventional products, which consumers willingly purchase due to their reasonable prices [80-82]. At the same time, international retail chains are introducing organic products under private labels to gain a competitive advantage. These products are much cheaper than organic products sold under manufacturers' brands [34]. Limited cooperation with other companies in the organic sector may also result in a higher competition and lack of economic benefits and is the most significant obstacle to sharing knowledge and resources [83].

Our research revealed that financial factors determining the macroeconomic situation of the country and directly related to the financial standing have an impact on the current operation, future development, and investment decisions. Surveys among farmers have shown that the important financial risk included high costs, considerable labor input [36,84], uncertain sales in the short or long term, market uncertainty or reduced revenues [63], and receiving inadequate prices for products $[67,68]$. Economic aspects (the possibility of obtaining subsidies and increased farm income) are cited as one of the most important reasons for switching to organic production [85-87], and lack of support or insufficient support is identified as an important barrier to the development of the organic sector [88]. Due to insufficient income from production [89], a significant number of Polish farmers are forced to look for other sources, and low yields and high production costs are some of their concerns [17]. Compared to conventional systems, labor costs are higher in organic farming, and the profitability of organic farms depends on price premiums for organic products [90-92]. Additionally, green, and sustainable finance combined with corporate social responsibility and intellectual and human capital have become central issues in measuring organizations' success, competitive advantage and influence on the market [93].

\subsection{Technological Limitations}

In our study, the managers of processing, distributing, and retailing companies identified that maintaining a stable raw material base, logistics, and production storage are the most important technological limitations which were associated with higher costs and lower profitability. Other studies conducted in Poland, as well as other countries, have also confirmed these limitations as negatively influencing the development of the organic food sector. A study carried out among Polish organic farmers [17] described that the limited access to resource base results in strong differences between demand and supply. Similar findings were presented by Aghasafari et al. [68], and their study identified that a limited supply of organic products in specialized stores and lack of access to organic resources and inputs affect the growth of the organic market. A study on organic milk production pointed out the lack of raw organic milk as a factor forcing domestic processors and retailers to import raw materials [94]. On the other hand, our results disagree with these of a Spanish study [92] which found a high availability of organic fruits and vegetables through direct sales from farmers. Some customers try to purchase organic foods outside of their usual shopping places, but to overcome this barrier, the availability of organic foods in modern distribution channels should be improved [92]. A study conducted among the US organic food retailers [95] showed that many companies are willing to help farmers to convert to organic food production as food companies aim to improve the availability of organic products in their supply chain. Moreover, some studies [36,65] have reported technical 
issues associated with organic production, such as poor distribution systems for products and limited processing capacities. Organic farmers also have limited access to established marketing channels, such as wholesale markets and supermarket chains [96].

Another study conducted in the US reported additional technological limitations in the organic sector [66]. The results indicated that producers were most concerned about the availability of organic processing facilities, lack of understanding of organic production methods, high input costs, and availability of organic inputs. Due to legal restrictions on the use of fertilizers and plant inputs, organic farmers should strive to maintain high yields $[97,98]$. Most importantly, in organic production, only organic fertilizers must be used, which often have to be imported [64]. Studies conducted in Germany [63] and Nigeria [84] have highlighted insufficient plant protection products as technical problems in organic farming, which may result in lower yields. Similarly, a Polish study showed that organic production is affected by agrotechnical factors, the need for maintenance of soil fertility, and the low availability of appropriate machinery and other equipment [17].

\subsection{Environmental Limitations}

The negative impact of weather on yields was identified as the most important environmental limitation in our study. Similar conclusions regarding the influence of weather and climate conditions on organic food production have been drawn from a study conducted in Serbia [79]. Yield variability caused by external conditions was indicated as an important barrier to organic farming [99]. Similar weather-related limitations were noticed not only for organic farming but also for other fields [100,101]. In addition, studies have pointed out natural capital problems such as location or diseases caused by insect pests $[65,84]$

The adoption of organic farming is also constrained by social factors [102]. The key social factors that were found to act as barriers to organic production were the attitude of family members, especially parents and other farmers (neighbors), toward organic production [69]. Other studies have indicated that the lack of belief in the benefits of organic production and skepticism from social networks create negative attitudes among farmers toward organic farming $[63,103,104]$. Furthermore, poor knowledge about organic farming principles and practices is perceived as another important sociocultural barrier to the development of organic farming [105]. In a broader perspective relating to experts and researchers in the sector, other factors of a social nature should be pointed out relating to insufficient consumer awareness and insufficient cooperation between organic farmers and agricultural advisory bodies [106].

\subsection{Recommendations for Policies to Support the Sustainable Development of the Organic Food Sector}

Based on our qualitative research among representatives of processing, distribution, and trading companies, several measures to ensure sustainable development of the organic food sector can be proposed. We focus entirely on the perspective of market actors as policies aimed at organic farmers are covered in other studies $[15,17,26,102,107]$. Processors, distributors, and retailers operating in the organic food sector face many uncertainties due to frequent law changes and ambiguous interpretation of organic and business law, posing financial risks to their businesses. The companies should be provided with legal and formal support. Programs aimed at improving knowledge transfer to organic processors, distributors, and retailers should be proposed to reduce the limitations arising from complex organic regulations. Thus, improvements in collaboration between government, science, production, distribution, and retail companies are crucial to support further growth of the organic food sector in Poland. Future policies should strengthen the development of new cooperation models within the organic food sector to overcome barriers related to maintaining a stable raw material base. 


\section{Conclusions}

Our study analyzed the factors limiting the development of the organic food sector from the perspective of processors, distributors, and retailers and revealed that several interrelated legal, economic, technological, and environmental barriers should be dealt with coherent policies to ensure further growth of the sector. The major obstacle resulting from the economic and technological issues is poor access to organic raw materials and products. Processing and retailing companies are dependent on foreign markets for sourcing raw materials and products and coping with fluctuating exchange rates. Economic factors are responsible for the increase in competition in acquiring raw materials, as well as determining the cost structure, production profitability, exchange rate differences, debt, and liquidity. The results of our study indicate sustainable supply of raw materials can be ensured by building long-term trust-based partnerships with local farmers based on the experience gained by processors and retailers.

Author Contributions: H.G.-W.-conceptualization, methodology, validation, formal analysis, investigation, data curation, writing — original draft preparation, writing-review and editing, visualization, supervision; S.Ż.-B.-conceptualization, methodology, validation, formal analysis, investigation, data curation, writing — original draft preparation, writing — review and editing, visualization, supervision, project administration, resources, funding acquisition; D.S.-conceptualization, methodology, validation, investigation, data curation, writing - original draft preparation, writing-review and editing, M.Ś- - conceptualization, methodology, validation, investigation, data curation, writingoriginal draft preparation, writing - review and editing; A.B.-conceptualization, methodology, validation, investigation, writing-review and editing, J.S.-conceptualization, methodology, validation, investigation, writing-review and editing, M.C.-investigation, data curation; K.K.- investigation, data curation, E.S.--investigation, data curation. All authors have read and agreed to the published version of the manuscript.

Funding: The research was funded by the Polish Ministry of Agriculture and Rural Development; research project titled "Marketing, promotion and market analysis of organic production in Poland, including opportunities and barriers of development", decision no. HOR.re.027.6.2017 of 26 May 2017.

Institutional Review Board Statement: The research was conducted within the project of the Polish Ministry of Agriculture and Rural Development titled "Marketing, promotion and market analysis of organic production in Poland, including opportunities and barriers of development", decision no. HOR.re.027.6.2017 of 26 May 2017. The APC was financed by the Polish Ministry of Science and Higher Education within funds of Institute of Human Nutrition, Warsaw University of Life Sciences (WULS) for scientific research.

Informed Consent Statement: Informed consent was obtained from all subjects involved in the study.

Data Availability Statement: Data are available at the Department of Food Market and Consumption research in the Institute of Human Nutrition Sciences, Warsaw University of Life Sciences, in Poland.

Conflicts of Interest: The authors declare no conflict of interest.

\section{References}

1. Willer, H.; Trávníček, J.; Meier, C.; Schlatter, B. The World of Organic Agriculture; Research Institute of Organic Agriculture FiBL \& IFOAM-Organics International: Bonn, Germany, 2021; ISBN 9783037362518.

2. Häring, A.M.; Vairo, D.; Dabbert, S.; Zanoli, R. Organic farming policy development in the EU: What can multi-stakeholder processes contribute? Food Policy 2009, 34, 265-272. [CrossRef]

3. European Commission. The European Green Deal; European Commission: Brussels, Belgium, 2019.

4. European Commission. Farm to Fork Strategy; European Commission: Brussels, Belgium, 2020.

5. European Commission. EU Biodiversity Strategy for 2030 Bringing Nature back into Our Lives; European Commission: Brussels, Belgium, 2020.

6. Seufert, V.; Ramankutty, N. Many shades of gray-The context-dependent performance of organic agriculture. Sci. Adv. 2017, 3, e1602638. [CrossRef]

7. Brzezina, N.; Kopainsky, B.; Mathijs, E. Can organic farming reduce vulnerabilities and enhance the resilience of the European food system? A critical assessment using system dynamics structural thinking tools. Sustainability 2016, 8, 971. [CrossRef]

8. Brzezina, N.; Biely, K.; Helfgott, A.; Kopainsky, B.; Vervoort, J.; Mathijs, E. Development of organic farming in europe at the crossroads: Looking for the way forward through system archetypes lenses. Sustainability 2017, 9, 821. [CrossRef] 
9. Committee and the Committee of the Regions. A Farm to Fork Strategy for a Fair, Healthy and Environmentally-Friendly Food System Contents. Available online: https:/ / agridata.ec.europa.eu/Qlik_Downloads/Jobs-Growth-sources.htm (accessed on 7 September 2021).

10. Harris, J.M. Global Development and Environment Institute Tufts University Ecological Economics of the Green New Deal. In Proceedings of the 2019 ESA Annual Meeting, Louisville, KY, USA, 11-16 August 2019.

11. Peeters, A.; Lefebvre, O.; Balogh, L.; Barberi, P.; Batello, C.; Bellon, S.; Gaifami, T.; Gkisakis, V.; Lana, M.; Migliorini, P.; et al. A Green Deal for implementing agroecological systems: Reforming the Common Agricultural Policy of the European Union. J. Sustain. Org. Agric Syst. 2020, 70, 83-93.

12. Golik, D.; Żmija, D. Rolnictwo ekologiczne i perspektywy jego rozwoju w Polsce w świetle doświadczeń unijnych. Zesz. Nauk. Uniw. Ekon. W Krakowie 2017, 1, 117-129. [CrossRef]

13. European Committee of the Regions. Biodiversity Strategy for 2030 Bringing Nature Back into our LIVES. Available online: https:/ / ec.europa.eu/research/environment/index.cfm?pg=nbs (accessed on 7 September 2021).

14. Adewale, C.; Reganold, J.P.; Higgins, S.; Evans, R.D.; Carpenter-Boggs, L. Improving carbon footprinting of agricultural systems: Boundaries, tiers, and organic farming. Environ. Impact Assess. Rev. 2018, 71, 41-48. [CrossRef]

15. Łuczka, W.; Kalinowski, S.; Shmygol, N. Organic farming support policy in a sustainable development context: A polish case study. Energies 2021, 14, 4208. [CrossRef]

16. Serwis Rzeczypospolitej Polskiej. Raport o Stanie Rolnictwa Ekologicznego w Polsce w Latach 2017-2018; Serwis Rzeczypospolitej Polskiej: Warszawa, Poland, 2019.

17. Łuczka, W.; Kalinowski, S. Barriers to the development of organic farming: A polish case study. Agriculture 2020, 10, 536. [CrossRef]

18. Nuutila, J.; Kurppa, S. The Finnish organic food chain-An activity theory approach. Org. Agric. 2016, 6, 49-56. [CrossRef]

19. Argyropoulos, C.; Tsiafouli, M.A.; Sgardelis, S.P.; Pantis, J.D. Organic farming without organic products. Land Use Policy 2013, 32, 324-328. [CrossRef]

20. Blaće, A.; Čuka, A.; Šiljković, Ž. How dynamic is organic? Spatial analysis of adopting new trends in Croatian agriculture. Land Use Policy 2020, 99, 105036. [CrossRef]

21. Willer, H.; Schlatter, B.; Trávníček, J.; Kemper, L.; Lernoud, J. The World of Organic Agriculture Statistics and Emerging Trends 2020; FiBL: Brussels, Belgium, 2020.

22. Agriculture, Forestry and Fishery Statistics: 2020 Edition; Publications Office of the European Union: Luxembourg, 2020; ISBN 978-92-76-21521-9.

23. De Cock, L.; Dessein, J.; De Krom, M.P. Understanding the development of organic agriculture in Flanders (Belgium): A discourse analytical approach. NJAS—Wagening. J. Life Sci. 2016, 79, 1-10. [CrossRef]

24. Sahm, H.; Sanders, J.; Nieberg, H.; Behrens, G.; Kuhnert, H.; Strohm, R.; Hamm, U. Reversion from organic to conventional agriculture: A review. Renew. Agric. Food Syst. 2013, 28, 263-275. [CrossRef]

25. Serebrennikov, D.; Thorne, F.; Kallas, Z.; McCarthy, S.N. Factors influencing adoption of sustainable farming practices in europe: A systemic review of empirical literature. Sustainability 2020, 12, 9719. [CrossRef]

26. Ferreira, S.; Oliveira, F.; Gomes da Silva, F.; Teixeira, M.; Gonçalves, M.; Eugénio, R.; Damásio, H.; Gonçalves, J.M. Assessment of Factors Constraining Organic Farming Expansion in Lis Valley, Portugal. AgriEngineering 2020, 2, 111-127. [CrossRef]

27. Guccione, G.D.; Pagliarino, E.; Borri, I.; Vaccaro, A.; Borsotto, P. A participatory analysis of the control and certification system in the italian organic rice value chain. Sustainability 2021, 13, 2001. [CrossRef]

28. Padel, S.; Vine, J.; Huber, B.; Stolze, M.; Jeperson, L.M.; Rüegg, E.; Meinshausen, F.F.; Compagnioni, A.; Pulga, A.; Belliere, S.R. The European Regulatory Framework and Its Implementation in Influencing Organic Inspection and Certification Systems in the EU; Organic Eprints: Tjele, Denmark, 2011.

29. Miśniakiewicz, M.; Łuczak, J.; Maruszewska, N. Improvement of organic farm assessment procedures on the example of organic farming in poland-recommendations for organic farming in Poland. Agronomy 2021, 11, 1560. [CrossRef]

30. Leitner, C.; Vogl, C.R. Farmers' perceptions of the organic control and certification process in Tyrol, Austria. Sustainability 2020, 12, 9160. [CrossRef]

31. Symbio. Symbio Annual Report; Symbio: Watford, UK, 2017; pp. 1-50.

32. Milošević, G.; Kulić, M.; Durić, Z.; Durić, O. The taxation of agriculture in the republic of serbia as a factor of development of organic agriculture. Sustainability 2020, 12, 3261. [CrossRef]

33. Euromonitor International Organic Packaged Food in Poland. Passport Euromonitor International. In Organic Packaged Food in Poland; Passport; Euromonitor International: London, UK, 2017; p. 10.

34. Górska-Warsewicz, H.; Żakowska-Biemans, S.; Czeczotko, M.; Świątkowska, M.; Stangierska, D.; Świstak, E.; Bobola, A.; Szlachciuk, J.; Krajewski, K. Organic Private Labels as Sources of Competitive Advantage-The Case of International Retailers Operating on the Polish Market. Sustainability 2018, 10, 2338. [CrossRef]

35. Nuutila, J.; Kurppa, S. Two main challenges that prevent the development of an organic food chain at local and national level—An exploratory study in Finland. Org. Agric. 2017, 7, 379-394. [CrossRef]

36. Kociszewski, K.; Graczyk, A.; Mazurek-Łopacinska, K.; Sobocińska, M. Social values in stimulating organic production involvement in farming - The case of Poland. Sustainability 2020, 12, 5945. [CrossRef]

37. Zuba, M. Szanse i bariery w integracji łańcucha żywności ekologicznej w Polsce. Zesz. Nauk. WSEI Ser. Ekon. 2011, 3, 261-288. 
38. Maria, Z.-C.; Aleksandra, K.; Louise, M.; Aneta, B. Organic milk supply in Poland: Market and policy developments. Br. Food J. 2019, 121, 3396-3412.

39. Wu, X.; Xiong, J.; Li, H.; Wu, H. The myth of retail pricing policy for developing organic vegetable markets. J. Retail. Consum. Serv. 2019, 51, 8-13. [CrossRef]

40. Bryła, P. Organic food consumption in Poland: Motives and barriers. Appetite 2016, 105, 737-746. [CrossRef]

41. Żakowska-Biemans, S. Polish consumer food choices and beliefs about organic food. Br. Food J. 2011, 113, 122-137. [CrossRef]

42. Zakowska-Biemans, S.; Sajdakowska, M.; Issanchou, S. Impact of Innovation on Consumers Liking and Willingness to Pay for Traditional Sausages. Pol. J. Food Nutr. Sci. 2016, 66, 119-127. [CrossRef]

43. Zakowska-Biemans, S.; Tekień, A. Free range, organic? Polish consumers preferences regarding information on farming system and nutritional enhancement of eggs: A discrete choice based experiment. Sustainability 2017, 9, 1999. [CrossRef]

44. Popa, M.E.; Mitelut, A.C.; Popa, E.E.; Stan, A.; Popa, V.I. Organic foods contribution to nutritional quality and value. Trends Food Sci. Technol. 2019, 84, 15-18. [CrossRef]

45. Łuczka, W. Institutional Barriers to the Development of Organic Farming in Poland. Roczniki 2020, XXII, 213-223. [CrossRef]

46. The Civil Law. Dz.U. 2018 poz. 1025 OBWIESZCZENIE 2018, 1025, 1-35.

47. Lune, H.; Berg, B.L.; Bethoney, L. Qualitative Research Methods for the Social Sciences; California State University: Long Beach, CA, USA, 2017; ISBN 0-13-420213-9.

48. Ayres, L. Semi-Structured Interview. In The SAGE Encyclopedia of Qualitative Research Methods; SAGE Publications, Inc.: Thousand Oaks, CA, USA, 2008.

49. Edwards, R.; Holland, J. What Is Qualitative Interviewing? A\&C Black: London, UK, 2013; ISBN 1849668027.

50. Kvale, S.; Brinkmann, S. InterViews: Learning the Craft of Qualitative Research Interviewing; Sage Publications: London, UK, 2009; ISBN 0761925414

51. Wilson, C. Semi-Structured Interviews. Interview Techniques for UX Practitioners. Interview Tech. UX Pract. 2014, 23-41. Available online: https: / / www.elsevier.com/books/interview-techniques-for-ux-practitioners/wilson/978-0-12-410393-1 (accessed on 15 June 2021).

52. Kallio, H.; Pietila, A.; Johnson, M.; Kangasniemi, M. Systematic Methodological Review: Developing a Framework for a Qualitative Semi Structured Interview Guide; University of Salford: Manchester, UK, 2016.

53. Lester, J.N.; Cho, Y.; Lochmiller, C.R. Learning to Do Qualitative Data Analysis: A Starting Point. Hum. Resour. Dev. Rev. 2020, 19, 94-106. [CrossRef]

54. Braun, V.; Clarke, V. Using thematic analysis in psychology. Qual. Res. Psychol. 2006, 3, 77-101. [CrossRef]

55. Ritchie, J.; Spencer, L. Qualitative data analysis for applied policy research. Anal. Qual. Data 2010, 173-194. [CrossRef]

56. Anderson, V. Criteria for Evaluating Qualitative Research. Hum. Resour. Dev. Q. 2017, 28, 125-133. [CrossRef]

57. BioPlanet. Bio Planet S.A. Annual Report; BioPlanet: Halle, Belgium, 2018.

58. Martins, J. Annual report 2016. Present. Rep. 2016. Available online: https://www.jeronimomartins.com/wp-content/uploads/ files \%20to\%20download/DOCUMENTOS\%20IR/RELATORIO\%20E\%20CONTAS/2016/EN/annualreportjm2016.pdf (accessed on 15 June 2021).

59. Auchan. Annual Financial Report Auchan Holding; Auchan: Croix, France, 2016.

60. Carrefour. Annual Financial Report 2016; Carrefour: Annecy, France, 2016.

61. Bazaluk, O.; Yatsenko, O.; Zakharchuk, O.; Ovcharenko, A.; Khrystenko, O.; Nitsenko, V. Dynamic development of the global organic food market and opportunities for Ukraine. Sustainability 2020, 12, 6963. [CrossRef]

62. Flaten, O.; Lien, G.; Koesling, M.; Valle, P.S.; Ebbesvik, M. Comparing risk perceptions and risk management in organic and conventional dairy farming: Empirical results from Norway. Livest. Prod. Sci. 2005, 95, 11-25. [CrossRef]

63. Siepmann, L.; Nicholas, K.A. German winegrowers' motives and barriers to convert to organic farming. Sustainability $2018,10,4215$. [CrossRef]

64. Noe, E.; Alrøe, H.F.; Thorsøe, M.H.; Olesen, J.E.; Sørensen, P.; Melander, B.; Fog, E. Knowledge Asymmetries Between Research and Practice: A Social Systems Approach to Implementation Barriers in Organic Arable Farming. Sociol. Rural. 2015, 55, 460-482. [CrossRef]

65. Doernberg, A.; Zasada, I.; Bruszewska, K.; Skoczowski, B.; Piorr, A. Potentials and limitations of regional organic food supply: A qualitative analysis of two food chain types in the Berlin Metropolitan region. Sustainability 2016, 8, 1125. [CrossRef]

66. Constance, D.H.; Choi, J.Y. Overcoming the barriers to organic adoption in the United States: A Look at pragmatic conventional producers in Texas. Sustainability 2010, 2, 163-188. [CrossRef]

67. Grover, S.; Gruver, J. "Slow to change": Farmers' perceptions of place-based barriers to sustainable agriculture. Renew. Agric. Food Syst. 2017, 32, 511-523. [CrossRef]

68. Aghasafari, H.; Karbasi, A.; Mohammadi, H.; Calisti, R. Determination of the Best Strategies for Development of Organic Farming: A SWOT_Fuzzy Analytic Network Process Approach; Elsevier Ltd.: Amsterdam, The Netherlands, 2020; Volume 277, ISBN 5138804677.

69. Home, R.; Indermuehle, A.; Tschanz, A.; Ries, E.; Stolze, M. Factors in the decision by Swiss farmers to convert to organic farming. Renew. Agric. Food Syst. 2019, 34, 571-581. [CrossRef]

70. CE. European Commission Directorate-General for Agriculture and Rural Development Frequently Asked Questions on Organic Rules. 2019. Available online: https:/ / ec.europa.eu/info/sites/default/files/food-farming-fisheries/farming/documents/ organic-rules-faqs_en_0.pdf (accessed on 15 June 2021). 
71. Gómez, M.I.; Barrett, C.B.; Buck, L.E.; De Groote, H.; Ferris, S.; Gao, H.O.; McCullough, E.; Miller, D.D.; Outhred, H.; Pell, A.N.; et al. Research principles for developing country food value chains. Science 2011, 332, 1154-1155. [CrossRef]

72. Jouzi, Z.; Azadi, H.; Taheri, F.; Zarafshani, K.; Gebrehiwot, K.; Van Passel, S.; Lebailly, P. Organic Farming and Small-Scale Farmers: Main Opportunities and Challenges. Ecol. Econ. 2017, 132, 144-154. [CrossRef]

73. Veldstra, M.D.; Alexander, C.E.; Marshall, M.I. To certify or not to certify? Separating the organic production and certification decisions. Food Policy 2014, 49, 429-436. [CrossRef]

74. Delbridge, T.A.; King, R.P.; Short, G.; James, K. Risk and red tape: Barriers to organic transition for U.S. Farmers. Choices 2017, 32, 10.

75. Zagata, L.; Sutherland, L.A. Deconstructing the "young farmer problem in Europe": Towards a research agenda. J. Rural Stud. 2015, 38, 39-51. [CrossRef]

76. Zoiopoulos, P.; Hadjigeorgiou, I. Critical overview on organic legislation for animal production: Towards conventionalization of the system? Sustainability 2013, 5, 3077-3094. [CrossRef]

77. Escribano, A.J. Organic feed: A bottleneck for the development of the livestock sector and its transition to sustainability? Sustainability 2018, 10, 2393. [CrossRef]

78. Dovleac, L.; Bălășescu, M. Barriers to the development of the short supply chain for local food producers in Romania. Bull. Transilv. Univ. Brasov. Econ. Sci. Ser. V 2017, 10, 35-44.

79. Vojinović, Ž.; Cvijanović, D. Risks in the Production of Organic Food 1; Institute of Agricultural Economics: Belgrade, Serbia, 2016.

80. Costanigro, M.; Mcfadden, D.T.; Kroll, S.; Nurse, G. An in-store valuation of local and organic apples: The role of social desirability. Agribusiness 2011, 27, 465-477. [CrossRef]

81. Greene, C.; Dimitri, C.; Lin, B.H.; McBride, W.; Oberholtzer, L.; Smith, T. Emerging issues in the U.S. organic industry. Emerg. Issues U.S. Org. Food Ind. 2011, 1-29. Available online: https://www.ers.usda.gov/webdocs/publications/44406/9397_eib55_1_.pdf (accessed on 15 June 2021).

82. Onozaka, Y.; McFadden, D.T. Does local labeling complement or compete with other sustainable labels? A conjoint analysis of direct and joint values for fresh produce claim. Am. J. Agric. Econ. 2011, 93, 689-702. [CrossRef]

83. Truant, E.; Broccardo, L.; Zicari, A. Organic companies' business models: Emerging profiles in Italian bio-districts. Br. Food J. 2019, 121, 2067-2085. [CrossRef]

84. Adebiyi, J.A.; Olabisi, L.S.; Richardson, R.; Liverpool-Tasie, L.S.O.; Delate, K. Drivers and constraints to the adoption of organic leafy vegetable production in Nigeria: A livelihood approach. Sustainability 2020, 12, 96. [CrossRef]

85. Palšová, L. Organic farming versus interest of the state for its support. Pol. J. Environ. Stud. 2019, 28, 2773-2784. [CrossRef]

86. Larsson, M.; Morin, L.; Hahn, T.; Sandahl, J. Institutional barriers to organic farming in Central and Eastern European countries of the Baltic Sea region. Agric. Food Econ. 2013, 1, 1-20. [CrossRef]

87. Eyhorn, F.; van den Berg, M.; Decock, C.; Maat, H.; Srivastava, A. Does organic farming provide a viable alternative for smallholder rice farmers in India? Sustainability 2018, 10, 4424. [CrossRef]

88. Wheeler, S.A. The barriers to further adoption of organic farming and genetic engineering in Australia: Views of agricultural professionals and their information sources. Renew. Agric. Food Syst. 2008, 23, 161-170. [CrossRef]

89. Prus, P. Farmers' opinions about the prospects of family farming development in Poland. In Proceedings of the 2018 International Conference "Economic Science for Rural Development", Jelgava, Latvia, 9-11 May 2018; Volume 47, pp. 267-274.

90. Crowder, D.W.; Reganold, J.P. Financial competitiveness of organic agriculture on a global scale. Proc. Natl. Acad. Sci. USA 2015, 112, 7611-7616. [CrossRef] [PubMed]

91. Khoy, R.; Nansek, T.; Chomei, Y. Farmers' Perceptions of Organic Rice Farming in Cambodia: Opportunities and Challenges. Int. J. Humanit. Soc. Sci. 2017, 7, 92-103.

92. Carmona, I.; Griffith, D.M.; Aguirre, I. Understanding the factors limiting organic consumption: The effect of marketing channel on produce price, availability, and price fairness. Org. Agric. 2020, 11, 89-103. [CrossRef]

93. Popescu, C.R.G.; Popescu, G.N. An Exploratory Study Based on a Questionnaire Concerning Green and Sustainable Finance, Corporate Social Responsibility, and Performance: Evidence from the Romanian Business Environment. J. Risk Financ. Manag. 2019, 12, 162. [CrossRef]

94. Duda, J.; Tlačbabová, M. Barriers to organic milk production. Acta Univ. Agric. Silvic. Mendel. Brun. 2012, 60, 55-60. [CrossRef]

95. Dimitri, C.; Baron, H. Private sector support of the farmer transition to certified organic production systems. Org. Agric. 2020, 10, 261-276. [CrossRef]

96. Zollet, S.; Maharjan, K.L. Overcoming the barriers to entry of newcomer sustainable farmers: Insights from the emergence of organic clusters in Japan. Sustainability 2021, 13, 866. [CrossRef]

97. Dayoub, M.; Korpela, T. Trends and challenges in organic farming in the European Union. Int. J. Agric. Technol. 2019, 15, 527-538.

98. Lavik, M.S.; Lien, G.; Korsaeth, A.; Brian Hardaker, J. Comparison of Conventional and IPM Cropping Systems: A Risk Efficiency Analysis. J. Agric. Appl. Econ. 2020, 52, 385-397. [CrossRef]

99. Trewavas, A. A critical assessment of organic farming-and-food assertions with particular respect to the UK and the potential environmental benefits of no-till agriculture. Crop Prot. 2004, 23, 757-781. [CrossRef]

100. Powell, J.P.; Reinhard, S. Measuring the effects of extreme weather events on yields. Weather Clim. Extrem. 2015, 12, 69-79. [CrossRef]

101. Liu, L.; Basso, B. Impacts of climate variability and adaptation strategies on crop yields and soil organic carbon in the US Midwest. PLoS ONE 2020, 15, e0225433. [CrossRef] 
102. Läpple, D.; Kelley, H. Understanding the uptake of organic farming: Accounting for heterogeneities among Irish farmers. Ecol. Econ. 2013, 88, 11-19. [CrossRef]

103. Duram, L.A. Agents' perceptions of structure: How Illinois organic farmers view political, economic, social, and ecological factors. Agric. Hum. Values 2000, 17, 35-48. [CrossRef]

104. Brock, C.C.; Barham, B.L. "Milk is milk": Organic dairy adoption decisions and bounded rationality. Sustainability 2013, 5, 5416-5441. [CrossRef]

105. Janjhua, Y.; Chaudhary, R.; Mehta, P.; Kumar, K. Determinants of Farmer's Attitude toward Organic Agriculture and Barriers for Converting to Organic Farming Systems: Research Insights. Int. J. Econ. Plants 2019, 6, 97-103. [CrossRef]

106. Żakowska-Biemans, S. Marketing, Promocja oraz Analiza Rynku, Analiza Rynku Produkcji Ekologicznej W Polsce, W Tym Określenie Szans I Barier Dla Rozwoju Tego Sektora Produkcji; WULS: Warsaw, Poland, 2017.

107. González-Azcárate, M.; Cruz Maceín, J.L.; Bardají, I. Why buying directly from producers is a valuable choice? Expanding the scope of short food supply chains in Spain. Sustain. Prod. Consum. 2021, 26, 911-920. [CrossRef] 